is the duty of every scientist, working through every educational device available, to keep the urban American aware of the natural condition of his country and of his interest in its preservation.

\section{LITERATURE CITED}

Cassirer, Ernst. 1944. An Essay on Man. Yale University Press, New Haven, Conn. $237 \mathrm{pp}$.

Farb, Peter. 1968. Rise and fall of the Indian of the wild West. Natur. Hist., $77: 32-41$.

Fertig, Fred. 1970. Child of nature, the American Indian as an ecologist. Sierra Club Bull., 55:4-7.

Kluckhohn, Clyde, and Henry A. Murray. 1956. Personality in Nature, Society and Culture. Alfred A. Knopf, New York, 701 pp.

Lyle, David. 1967. The Human race has maybe, thirty-five year's left. Esquire, 68:116-118.
Martin, Paul S., and H. E. Wright, Jr. (Eds.). 1967. Pleistocene extinctions. Proc. 7th Cong. Int. Assoc. for Quaternary Res., Vol. 6. Yale University Press, New Haven, Conn.

Meier, Richard L. 1966. Technology, resources and urbanism-the long view. In: Future Environments of North America, F. Frazer Darling and John P. Milton (Eds.), Natural History Press, Garden City. pp. 277-288.

Roszak, Theodore, 1969. The Making of a Counter Culture. Doubleday \& Co., Garden City, N.Y. 303 pp.

Tuan, Yi-Fu. 1970. Our treatment of the environment in ideal and actuality. Amer. Sci., $58: 244-249$.

Udall, Stewart, L. 1964. The Quiet Crisis. Avon Books, New York. 244 pp.

Wheat, Joe Ben. 1967. A Paleo-Indian Bison kill. Sci. Amer., $216: 44-52$.

White, Jr., Lynn. 1967. The historical roots of our ecologic crisis. Science, 155:1203-1207.

Wright, Richard T. 1970. Responsibility for the ecological crisis. BioScience, 20:851-853.

\title{
THE ENVIRONMENTAL CRISIS IN THE ARCTIC
}

by Dalton Muir, Canadian Wildlife Service, Ottawa

As the events of this day* fall into place, it is well to remember what has transpired. We have witnessed the emergence of a new entity, a national federation with a past heritage and a future role. Three concepts are represented:

- the basic human desire to understand the natural world,

- the human need for a high quality environment,

- acknowledgement that this need has not been met by our social and economic development to date.

This federation implies concern, insight and determination to change concept into reality. The federation is acquiring the necessary funds, identity, constitution and executive direction. It has the most opportune moment in the history of Canada for its emergence. Ten years ago would have been premature and unconvincing, ten years from now will be too late. At this time we have numerous crises, public awareness, and a popular demand for action. The tools for democratic change are at hand, a brand new federal department of the environment and provincial counterparts. The federation's key posi-

*This paper was read at the inaugural meeting of the Canadian Nature Federation, September 18, 1971. tion between public and government is appropriate. Support from many like-minded organizations is assured and the stated principles and objectives of the federation cannot be attacked. The role is custom-tailored and waiting.

If all were well in the environment this federation probably would not be necessary and would not appear. We would still have the idyllic situation, long since departed, when there was plenty of natural environment for everyone. In those times, the very few natural scientists pursued strange pastimes and sought the close company of a few others of like mind nearby. These corresponded with distant colleagues, also few in number. To the venerable gentlemen who founded the Ottawa Field Naturalists in 1879 and the tiny Great Lakes Ornithological Club in 1905, the present hierarchy of provincial federations, national federations, international unions and world conferences on the environment would be mind-boggling. Now, less than 100 years later, the weight of current publications on natural history and the environment would soon surpass their lifelong library collections and would split their sagging shelves.

But all is not well in the environment. Both the quantity and the 


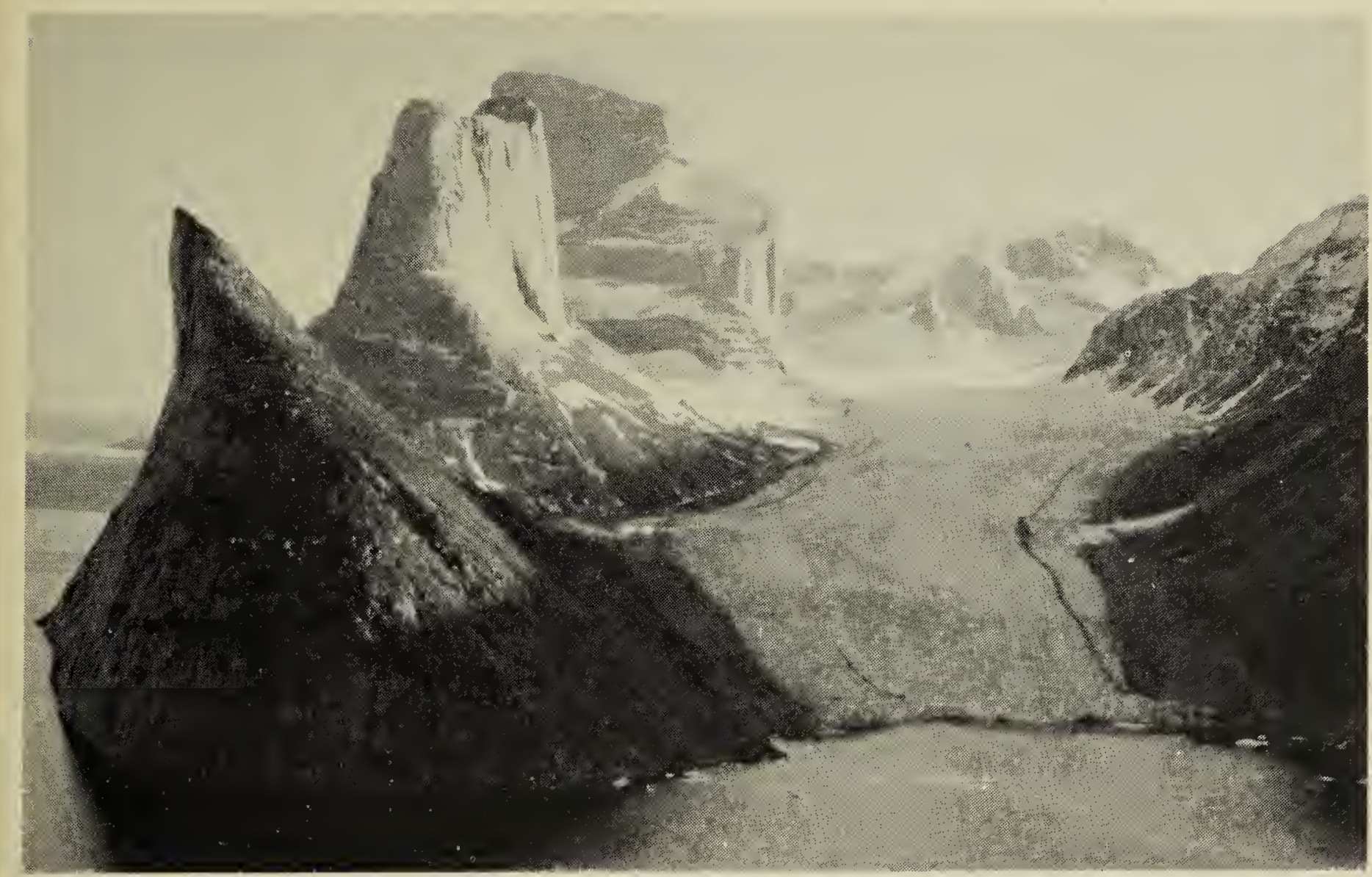

Arctic beauty at Baffin Island

Photo by Dalton Muir

quality of desirable environment are decreasing. Alarm has been raised and action has resulted. Departments of the environment at federal and provincial levels now exist. They are dealing with problems in the urban environment and problems in the provincial countryside.

There is one part of Canada that we tend especially to forget unless some news item using the word "Arctic" comes to our attention. At such times we tend to wonder how there could be problems in the Arctic, "it is so big," "there are so few people!" "It doesn't seem to be good for anything unless maybe for oil," and as an afterthought, "it does belong to us doesn't it?"

Our Arctic regions make up about one-third of Canada, depending on how you define "Arctic." It belongs to us. It is huge. It is strange. It is full of life and it is beautiful. It is the last true frontier, the last empty land. It is the ultimate challenge for Canada and Canadians.

For as long as I can remember there have been films, books, articles, TV programs and speeches on "Canada's awakening north." Until six years ago these statements were, at best, exaggeration. Then the search for resources began in earnest and this search continues at a faster pace each year. Some of what has happened to date is grossly damaging. Our remotest Arctic is beset by problems: roads, vehicles, airports, too much "civilization", sewage, garbage, spilled oil, abandoned debris and an attitude that "it's only the Arctic; it doesn't matter." But does it really matter, and if so, why?

At times like this I like to recall how a well-known movie actress some years ago played the part of a small town girl who had never travelled. When asked why she had not travelled, she replied, "I walked to the edge of town once and looked out, but there didn't seem to be much out there." Let us now see if there is anything "out there", in our Arctic.*

Looking at the land is an old custom even here in the new world. The early explorers and developers of this con-

\footnotetext{
*Accompanying his address, slides of the Arctic were shown to the meeting by Dalton
} Muir. 


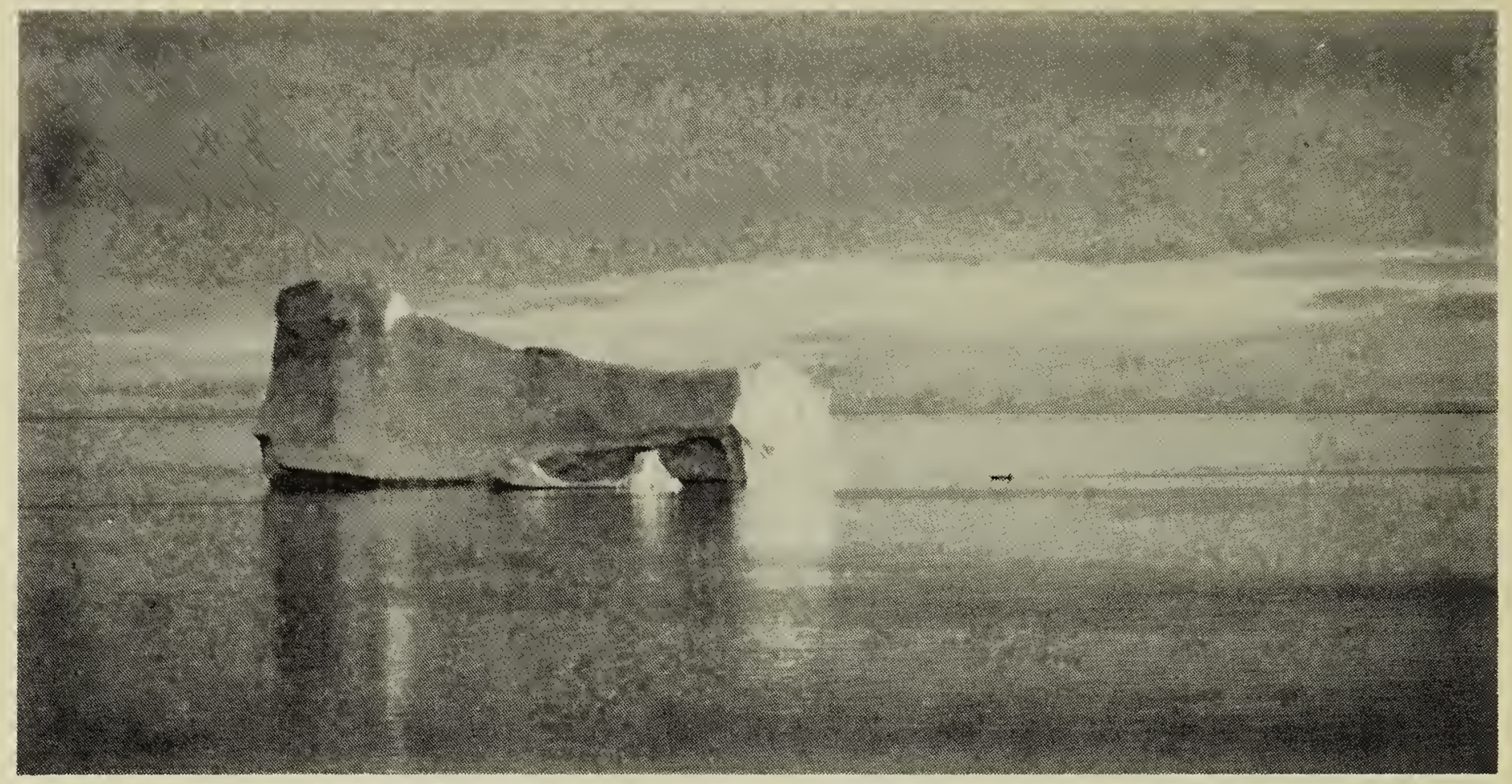

Iceberg at Bylot Island

Photo by Dalton Muir

tinent looked and noted the obvious resources, potentials, dangers and hardships. They also felt the awesome beauty in vast expanses of unoccupied natural landscape. They wrote of it in respectful tones. Men like Champlain, Rogers, Marquette and Joliet, Lewis and Clark, La Vérendrye and Palliser, looked at the mid-continent. Others such as Mackenzie, Hearne, McClintock, Hudson, Greely, and the ill-fated Franklin and Hall looked farther north. They too were able to see beyond the horror and hardship and speak of the strange beauty that stretched before them. Our nation has been looking at the Arctic with considerable interest in the last few years. But have we been looking with the eyes of men, a memory of evolving society and ability to plan for the future, or have we looked with the eyes of animals, eyes that see only food or danger and comprehend only the easy kill or the empty landscape and the empty stomach?

Evenis are moving forward, the Arctic is awake, the rush for resources is on. This rush has changed the face of the Arctic more in the last five or six years than had all previous human activity to that time. The combined effect of hundreds of years of Eskimo occupation, the early explorers, weather stations, defence installations, scientific activities and permanent European settlements has left its mark upon the land, but it is small compared to the heavy footprint of "the great resources rush."

This rate of change is not matched by the natural rate of growth and recovery of the Arctic environment. The marks of the early explorers are still visible in some places and the heavy imprint of the first vehicles in the Arctic is still very clear. Last year I saw again vehicle tracks which I had seen 15 years previously and found that they had not changed appreciably during that time.

Arctic plants grow and spread slowly. A sample of Arctic willow which I collected, when examined under the microscope, proved to have annual rings one cell thick. The stem of this creeping Arctic plant had increased in diameter so slowly because the cambium layer had divided only once each year. Willow is possibly the most important single food plant in the Arctic. With this low growth rate the total productivity of living communities on land must be very low indeed.

When a herd of Muskox or Caribou is spotted from an aeroplane, one is tempted to say "there are dozens of 
them." If a second or third herd is visible from the air at the same time in an unusually rich area, one is tempted to conclude that the Arctic landscape is overrun with game. But you must remember that you may be looking at all of the game in 500 square miles or more. And even this kind of abundance is possible only in limited and unusually rich areas. In much of the Arctic it is possible to pass over many, many hundreds of square miles and see no game animals at all. The well-known game ranges such as the South Melville Island Caribou range and the Foshiem Peninsula Muskox range on Ellesmere Island are probably unique in the entire Arctic. They in no way represent the productive capacity of the Arctic region as a whole.

The Arctic region and in particular the high Arctic islands have one characteristic which is of great interest to science and of potential value to society. The wab of life, the so-called ecosystem, is a simplified one. There are relatively few species and the theoreti. cal number of possible interactions is limited. Food chains and pyramids of numbers are short and truncated. Single species dependencies are common and the loss or introduction of one species may be disastrous. An area with these characteristics is of particular value to science as a natural laboratory for the investigation of the characteristics of ecosystems. As the human population approaches the carrying capacity of our planet, it will become more important to understand clearly basic characteristics and limiting factors of the ecosystem.

It is of special interest to Canadians that this reduced ecosystem of our Arctic is something like a replay of our origins and past history in southern Canada. The whole Canadian landscape, at least all of it that matters for present purposes, was glaciated, covered deeply by ice during the last ice age. All plant and animal life that we know today as being "natural" or "native", has arrived and developed since the ice left. Unless we understand what potentials and limitations are im- posed on us by our past, we cannot plan with certainty for the future.

Another special characteristic of this Arctic ecosystem is of importance to science and hence to mankind. The Arctic ecosystem is one of the very few ecosystems which persist under approximately the same conditions in which ihey evolved. The importance of this characteristic may not at first be obvious but there is reason to believe it may be an important clue to understanding the whole natural order.

The Arctic has been described as sensitive and fragile. These terms may sound strange to us down here. What can be harder or more durable than mountains, glaciers and permanently frozen ground? How can these be fragile? The answer is that if they melt only a little, they become very vulnerable indeed, more so than if they stayed completely frozen, or if they melted completely each year as our land does down here. This thin layer of melted soil, the so called "active layer", is the Achilles' heel of the Arctic landscape and therefore of most living things in the Arctic. Much of the Arctic soil is fine silt, sediment, clay and peat. In

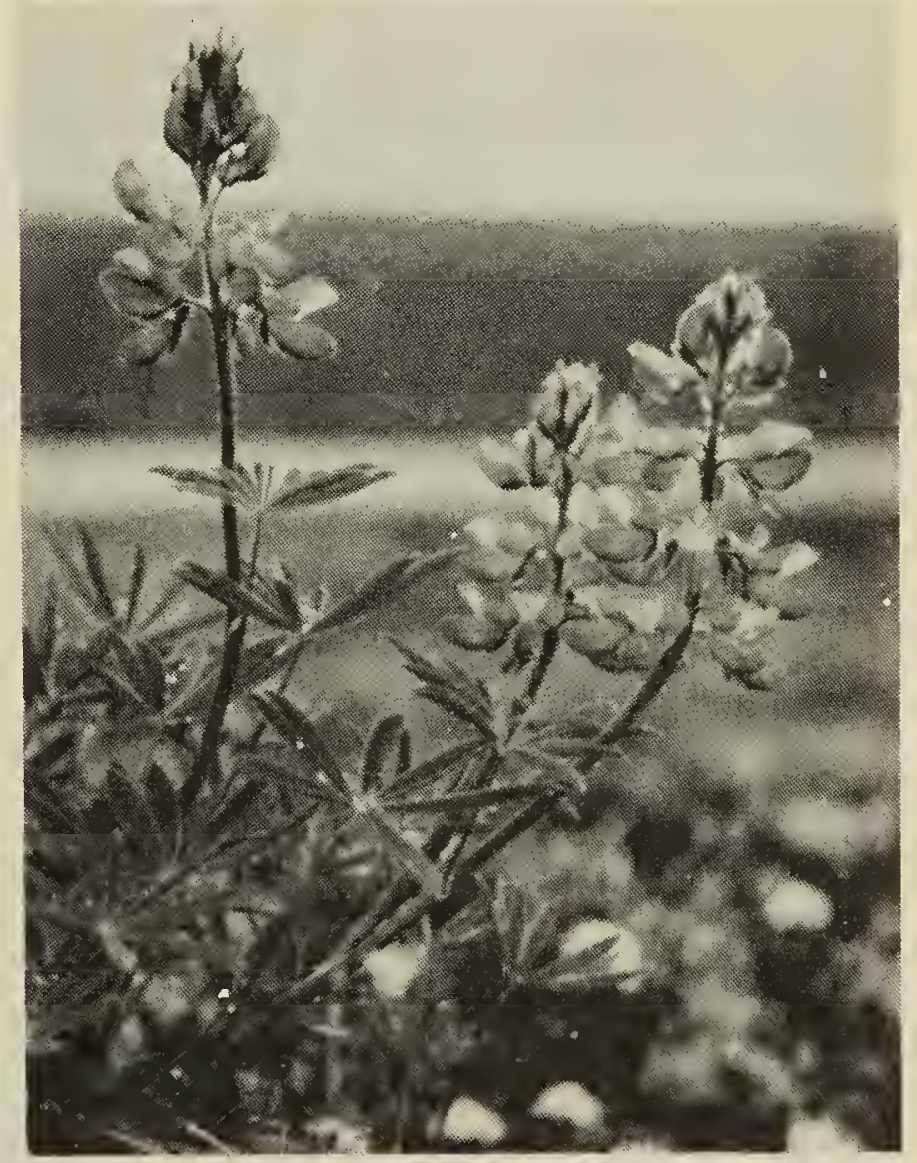

Photo by D. Muir

Arctic lupine at Lupine-Tuk

Penninsula 
the spring, as it melts downward a foot or so, it becomes waterlogged. It takes on the consistency of bread dough or, with a little more water, becomes like stew. It is greasy and slippery beyond belief, sticky as only those familiar with prairie gumbo can appreciate. It cannot drain downward because of the thousand feet of permanently frozen ground beneath. The soupy or doughy soil washes away with the spring run-off, slides downhill in sheets over the slick frozen soil beneath, or falls away from cliff faces and steep hillsides. Soils which have stabilized over the centuries are bleached by sun and soluble minerals are leached out by water. The surface tends to be light in colour. Any activity which breaks through this lightcoloured surface skin exposes the darker and wetter soil beneath. A bulldozer is a nearly perfect instrument for this purpose. The exposed dark soil traps more of the sun's heat than undisturbed land near by, causes increased melting of the permafrost and creates a pocket of deeply-thawed, wet soil. If the water can escape downhill it does so, carrying with it most of the newlythawed soil and starting a chain reaction of progressive erosion. We call this landscape fragile because it reacts to a small local change by producing a large widespread progressive result. Eventually, of course, a new equilibrium is established, but it is scores or hundreds of years before the slow pro. cess of revegetation produces useful food for animals. Much of the high Arctic landscape possesses this unstable characteristic. This factor is of critical importance to wildlife because the best wildlife range vegetation is usually found on rich, fine silty soils, the most unstable kind that the Arctic has to offer.

How serious is the damage to the Arctic? The question is too complicated to answer fully here but I will try to give you a broad general view of it.

\section{EXTENT}

Every major Arctic island and the Mackenzie River lowlands bear the marks of resource exploration, most of it in the search for oil. The territorial mainland lying within the Precambrian region, along with Baffin Island, is spotted with mineral resource activities. The Hudson Bay lowlands are being probed. Vast stretches of sea between the Arctic islands and much of Hudson Bay itself are also being

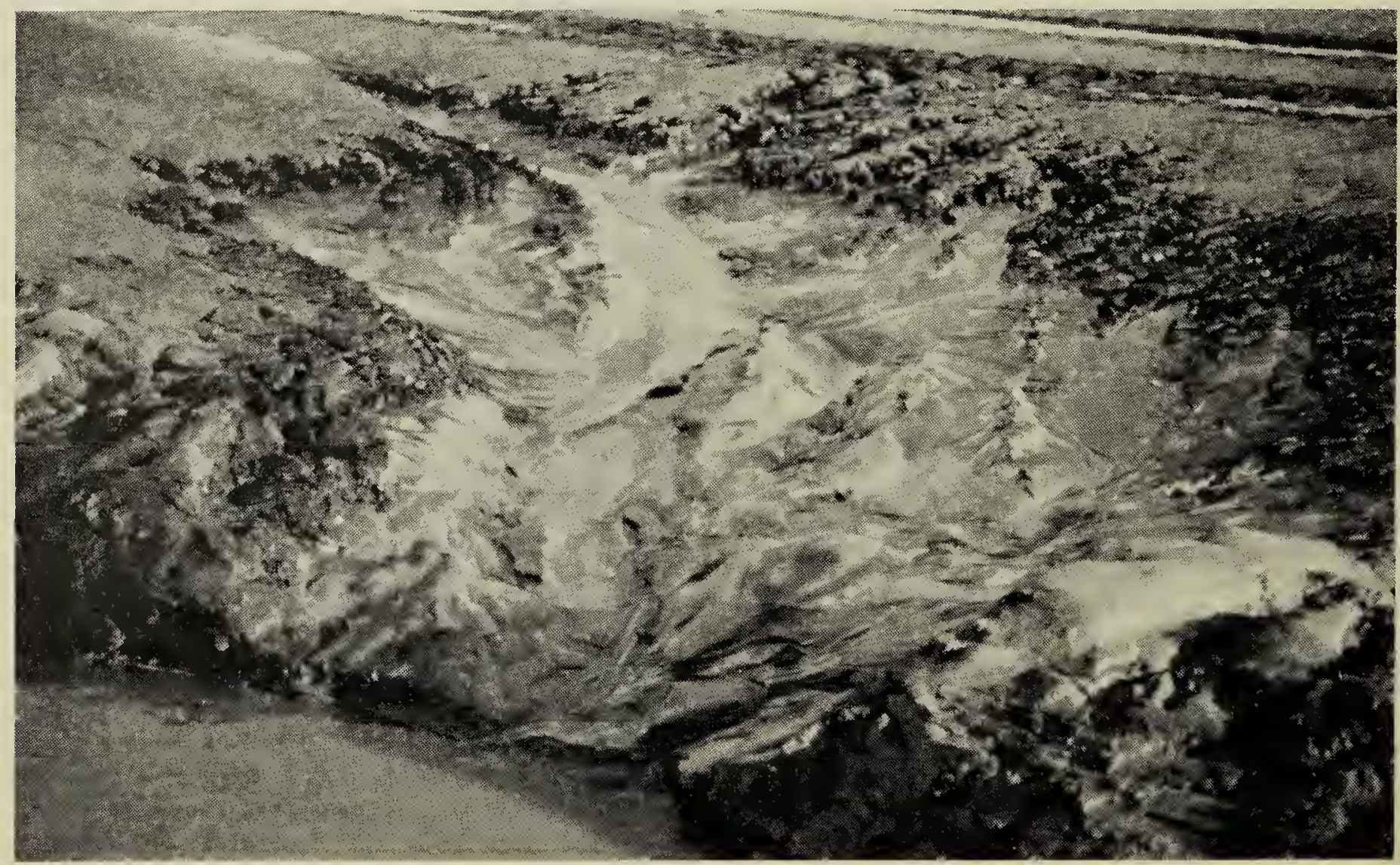

Erosion below a bull-dozer track

Photo by Dalton Muir 


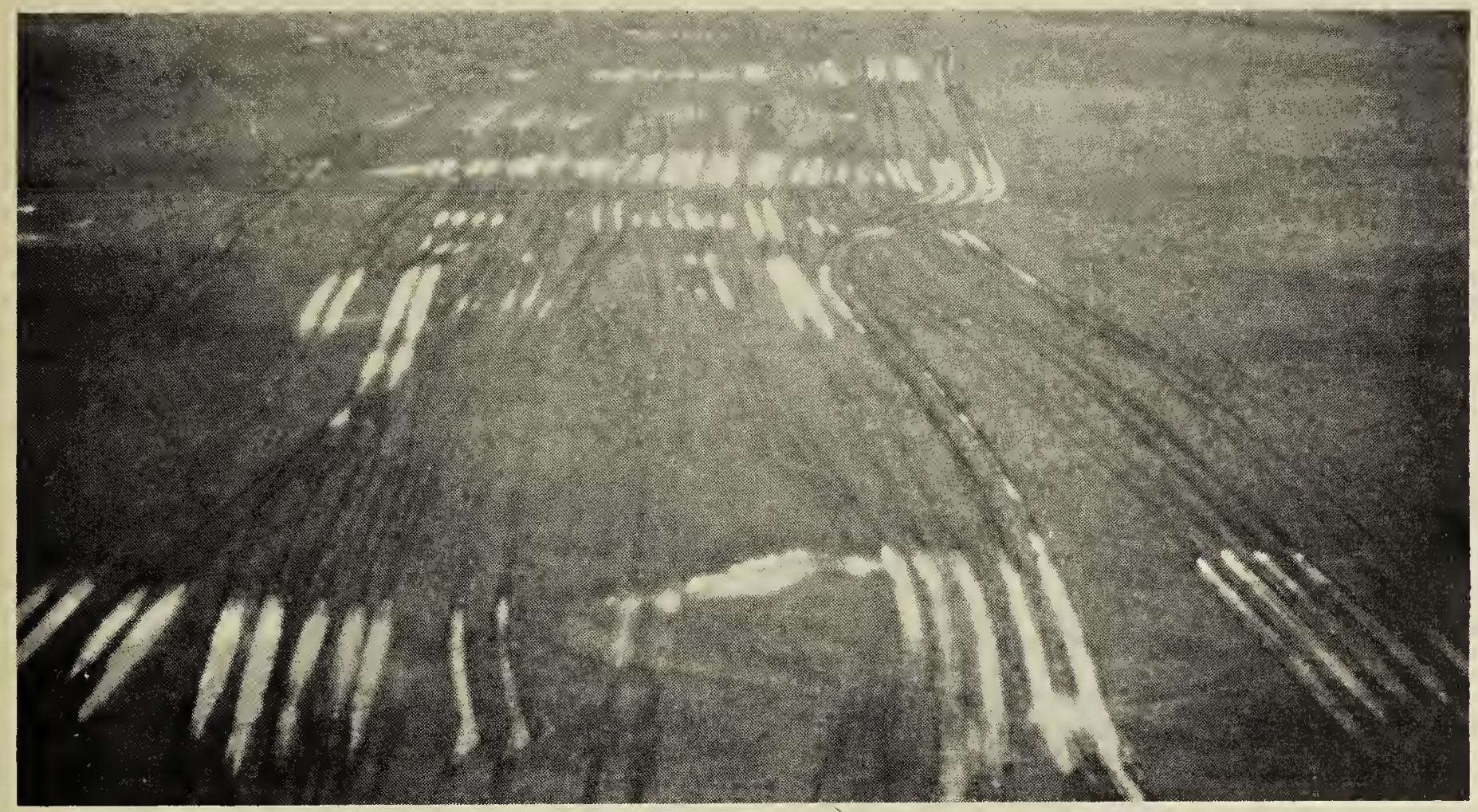

Scars on a fragile environment

Photo by Dalton Muir

probed. The Beaufort Sea, Baffin Bay and Fox Basin are relatively new "hot spots."

\section{IMPACT}

In general, seismic prospecting for oil during the summer months does the most widespread, serious and long lasting damage to the landscape. Summer use of tracked vehicles for point to point overland transport of materials is grossly damaging and is second only to seismic activity as a source of terrain damage. Drilling for oil produces utter devastation locally, on the sites themselves, and around the mile-long airstrips used to transport the rigs and other equipment. These sites, of course, are relatively small, a few acres for a rig, half a square mile for an airstrip. However, construction of several successive airstrips around a single activity centre is commonplace when the original strip site is poorly chosen or inadequately prepared. Square miles of natural terrain are effectively obliterated. Mineral prospecting usually is a small scale operation; however, a mine and associated facilities, particularly if it is an open pit complex such as at Pine Point, may destroy many square miles of landscape. The overall impact of all activity appears most serious on the rich tundra of the Tuk Peninsula and on the mud environment of the high Arctic islands, especially Melville Island. Effects range from slight damage to total obliteration. The Arctic terrain will recover from slight damage but it will not recover from total obliteration and progressive erosion within a human lifetime, probably not for centuries.

\section{FUTURE}

What of the search for resources? It will go on increasing in pace and extent for many years, even if nothing more is found. If hoped-for resources are discovered, the resulting burst of development activity will be limited only by the extent of the discovery and the hope that it holds out for further discovery.

Can the search for resources in the Arctic be stopped? The answer is a firm NO. And it should be added that in the interests of our resourceconsuming society, the search should not stop.

Can activity and damage in the Arctic be controlled and lessened? The answer here is a resounding YES. The damage in the Arctic to date is largely the result of haste, inadequate research and planning, trial and error methods 
using the cheapest way, the mistaken assumption that there is nothing else of value in the Arctic, and a general disregard for the ethics of landscape use. These problems can be solved through a combination of education, experience and legislative control. The forthcoming northern land use regulations should improve the situation. My branch, the Canadian Wildlife Service, now in the department of the environment, has produced preliminary ecological maps of the Arctic. My own work consists mostly of adding to ecological and environmental information on the Arctic islands and monitoring the possible effects of all human activity on wildlife in the Arctic.

\section{PROGRESS}

It is very important to note here that during the past year there has been a marked improvement in the operating procedures of most well known oil companies in the Arctic. The brand name companies that you would recognize at local gas stations are trying with considerable success to clean up their Arctic operations, probably out of a combination of genuine concern and a desire to preserve the corporate image. It should be stressed that while there has been improvement, much more improvement is needed before acceptable conditions prevail. If all else fails, legislative regulations will be available which can close down an operation.

From such glum topics let us turn to look at the bright side of the picture in the Arctic. I refer to the aesthetic value of the Far North. I have left this topic for the end because it may well be the longest-lasting, most beneficial and certainly the most enjoyable resource the Arctic has to offer. You have all seen something of the beauty of the Arctic through photographs. There is practically unlimited scope for exploration and travel on Canada's last frontier. Summer temperatures are invigorating. There are no flies to speak of if you go far enough north. There is bright twenty-four hour daylight. The landscape of mountains, glaciers, icebergs, with strange plants and animals, unusual land forms and vast reaches of solitude is ready-made for the person who wants to get away from it all or experience something new and different. The high Arctic was once inaccessible. You can now buy your air ticket over the counter in Montreal or Edmonton and have stewardesses serve food and drink all the way into Resolute Bay in the centre of the high Arctic islands. A plain but adequate hotel with bar awaits you there. Five minutes walk from the hotel, a commercial charter airline will fly you anywhere in the Arctic in a fleet of planes ranging from fabriccovered Cubs to a DC3. This year in the western Arctic, a commercial tourist agency started taking visitor groups down the Mackenzie river and over to Tuktoyaktuk. My own mother was on one of the first trips and I would refer you to her for a glowing account of the experience. I darkly suspect she is working for the travel agency in a public relations capacity.

Where does Canada stand now in the Arctic? The Arctic is ours, it is vast, rugged and beautiful. There are known valuable resources in the Arctic and the chances of vast wealth are good. The Arctic has already suffered widespread and serious damage and there will be more damage. Governmental control over activities is expected to reduce the rate, seriousness and impact of environmental damage. What of the future? I suggest to you that no matter what resources may or may not be found in the Arctic, the greatest long term benefit to Canada from our Arctic environment may well be a "safety valve" effect to relieve the pressures of too many people, too much stress and conflict, too much pollution and degraded environment. These benefits and the deeper insight into the total Canadian environment gained through study of our Arctic lands may well be our most priceless heritage, a resource not available to some less fortunate societies.

Groups such as the Canadian Naturt Federation can perform a valuable service by pressing for maintenance of environmental quality in Canada, especially in that less-known one-third of our land which we call "Arctic". 